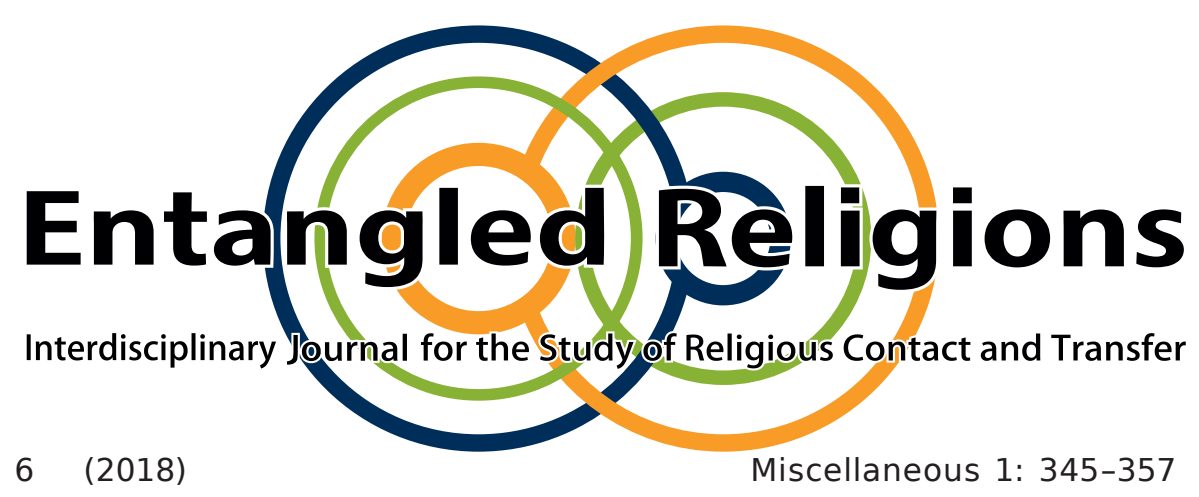

\title{
Groundwork, Fieldwork and
} Transnational Research

Christians and Jews in Ethiopia

STEVEN KAPLAN

Department of Comparative Religion, Hebrew University of Jerusalem, Israel

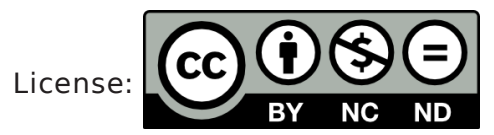

This contribution to Entangled Religions is published under the Creative Commons Attribution-NonCommercial-NoDerivatives 4.0 International Public License (CC BY-NC-ND 4.0 International). The license can be accessed at http://creativecommons.org/licenses/ by-nc-nd/4.0/ or is available from Creative Commons, 559 Nathan Abbot Way, Stanford, California 94305, USA

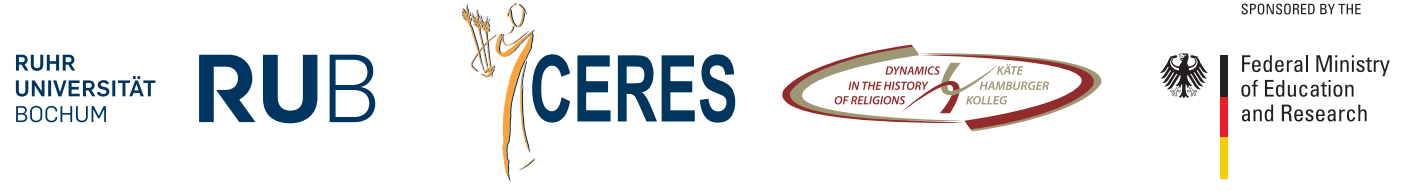




\title{
Groundwork, Fieldwork and Transnational Research
}

\author{
Christians and Jews in Ethiopia
}

\author{
STEVEN KAPLAN \\ Hebrew University of Jerusalem, Israel
}

\begin{abstract}
This paper gives a short overview of the current state of research of the study of Beta Israel history, including a response to two papers in this volume by Dege-Müller and Kribus and Krebs that deal with various Beta Israel sources.
\end{abstract}

KEY WORDS falasha; Beta Israel literature; Ethiopia; historical archaeology

The past four decades have been unprecedented in the history of the Beta Israel (Fälasha). Beginning in 1977, when a small group legally emigrated to Israel, their lives have been transformed. Today, almost the entire community, some 135,000 individuals, reside in Israel (Kaplan and Salamon 2014).

Ironically, their departure from Ethiopia coincided with the rise of a new scholarly paradigm, which began to place their history and culture firmly in the context of Ethiopia. While popular images, especially in Israel, continued to invoke "Lost Tribes" and a return after thousands of years in exile, academic literature began to reveal the depth of their roots in Northeast Africa. Pioneering works such as those of Shelemay (1989) and Quirin (1992), which were based on fieldwork carried out in the last years before the Ethiopian revolution, ${ }^{1}$ were, over time, supplemented by other

1 Both Shelemay and Quirin completed their dissertations in 1977, the same year as the first legal Beta Israel immigration to Israel. 
contributions primarily based on work carried out in Israel (Kaplan 1991; Salamon 1999). To this must be added the work of the prolific anthropologist Jon Abbink (1987, 1990).

In recent years there has been a decided shift. Even if we exclude from our purview the countless studies of the Ethiopian immigrants in Israel, there has also been a clear change in the types of sources used. Shelemay (1989) not only collected oral traditions, but superbly documented Beta Israel liturgical practice in situ. Her conclusion that what she had collected was not a long-preserved ancient Jewish ritual, but a sacred tradition intimately linked to Ethiopian Christian monasticism, has raised hackles, but has not been seriously challenged academically. ${ }^{2}$ Quirin (1992), also working in Ethiopia, collected oral histories from dozens of informants. His attempt to understand the Beta Israel as a caste-like group within Ethiopian society has proven a starting point for almost all historical work that has followed. While he is less polemical on the ethnogenesis of the "Fälasha" than Shelemay, Kaplan, and a host of other authors, his work remains a model of careful and balanced scholarship. Salamon's work (1999), while largely retrospective, demonstrates that memories of life in Ethiopia reveal a hitherto overlooked complexity in Jewish-Christian relations. Since then, her work on a variety of topics, including slavery, cattle, and meat (1994, 2003, 2008, 2015), have provided some of the most vivid descriptions of a world that largely survives only in the anecdotes, proverbs, and reminiscences of living in Israel.

Despite these achievements, much work remains to be done. One of the clear paths forward in the study of Beta Israel-Christian relations will be the formulation of a clearer chronology of the various "Jewish/Hebraic/Biblical"

2 A joint French Israeli project to document and re-analyze Beta Israel liturgy based in Israel was undertaken in the early 1980s. As of this writing, more than thirty years after its initiation, it has yet to produce major findings (cf. Tourny 1997). 
elements in Ethiopian Christianity. Only piecemeal progress has been made on this score, and we are still today largely caught between those who view Jewish elements as "survivals" from an early period in Ethiopian history (cf. Ullendorff 1956) and those who are more inclined to date them to later periods, particularly that of the powerful emperor Zär'a Ya'əqob or even later (Rodinson 1964a, 1964b). ${ }^{3}$ Certainly the time has come for a more nuanced view. While it is fairly clear that Aramaic loanwords must date, in the classic phrase of H.J. Polotsky $(1961,10)$, to the Pre-Christian “Jewish leaven in Ethiopian culture", many other elements would appear to be later, even much later. While some have dated the Solomonic legend Kəbrä Nägäśt as early as the sixth century CE (Shahid 1976), most scholars tend to opt for a later date for at least some of its elements (Munro-Hay 2001; Johnson 1995). Curiously, the identification of the Ethiopian monarchy with both the Lion and the Tribe of Judah probably dates to the sixteenth century and may even be an "invention" of the Portuguese (Rubensen 1976). The tri-partite division of Ethiopian churches, reminiscent of the Biblical Temple, does not appear to be an archaic element (Heldman 2003), and has been dated to the fifteenth or sixteenth century as well.

Moreover, a host of Biblically themed works possessed by both Ethiopian Christians and the Beta Israel (The Testaments of Abraham, of Isaac, and of Jacob, The Death of Aaron, The Conversation of Moses on Mount Sinai), appear to have originally reached Ethiopia in Arabic and thus cannot date earlier than the thirteenth or fourteenth century (Kaplan 1990).

Prior to the 1970s, there is little question that the study of Beta Israel literature took pride of place in the examination of their culture. Beginning with Joseph Halévy (1902), scholars trained in Semitic languages, such as

3 Many of the key articles in this debate-Ullendorff (1956), Rodinson (1964a, 1964b) and Polotsky (1964) - have been reprinted and, in the case of Rodinson, translated into English in Bausi 2017. See also Munro-Hay (2001) and Johnson (1995) on the Kəbrä Nägäśt. 
Aescoly (1951), Leslau (1951), Ullendorff (1961), and Wurmbrand (1961, 1962, 1963a, 1963b, 1964), produced editions and translations of their key works. Although these publications were based on an extremely limited corpus of manuscripts, they played a major role in shaping the image of the Beta Israel. Indeed, given the small number of such manuscripts and the fact that most Beta Israel could not read or even understand these texts in Ge'ez, one is inclined to suggest that their significance for an understanding of the Beta Israel may have been overstated. We would do well to consider more seriously the oral component in the transmission of elements within and between Jewish and Christian culture in Ethiopia.

Having said this, it must be noted that in recent decades, there has been a dramatic rise in the number of Ethiopic manuscripts available to scholars both on microfilm and digitally. It is no exaggeration to say that our knowledge of the history of Ethiopic literature has grown exponentially over the past half century.

Thus, the contribution of Sophia Dege-Müller is particularly welcome. Trained in the Hiob Ludolf Centre for Ethiopian Studies at the University of Hamburg, she possesses all the tools to make a truly original contribution to Beta Israel studies. Already in the present article she makes note of a new Beta Israel manuscript which she catalogued as part of the EthioSPARE project, headed by Denis Nosnitsin. ${ }^{4}$ Significantly, it contains at least two compositions not previously listed in studies of Beta Israel literature. Doubtless a wealth of other works remains to be discovered.

4 Səm'u wä-ləbbəw 'o-däqiqä 'Adam "Listen and understand O children of Adam..."; Gädlä 'Abrəham "Vita of Abrəham"; Nägärä bä-’əntä 'aśärtu qalat "Story of the Ten Commandments" (https://mycms-vs03.rrz.uni-hamburg.de/domlib/receive/domlib_docu ment_00002433?cnDesc=1\&images=no\&gen). It is unclear if Gädlä 'Abrəham "Vita of Abrəham" is a new work or a copy of the work known as the Testament of Abreham.. 
Certainly, the time has come for a new version of Wolf Leslau's Falasha Anthology. While the title will obviously have to be redone to reflect modern sensibilities, an Anthology of Beta Israel Literature: The Literary Heritage of Ethiopian Jewry will certainly serve many purposes. On the one hand, a clear English translation will make new works accessible and provide better versions of "familiar" texts. In this context, it should be noted that to do justice to the rich oral culture of the Beta Israel, any such volume must contain samples of important oral "texts". On the other, a proper critical edition, particularly one which traces the links between existing Beta Israel manuscripts and Christian exemplars of similar works, will deepen our understanding of the shared cultural milieu of the two groups. In this context, it should be noted that Ted Erho, in a recent discussion of "The Library and Old Testament Manuscripts of Gundä Gunde", reports that several of the manuscripts in the collection contain what was previously

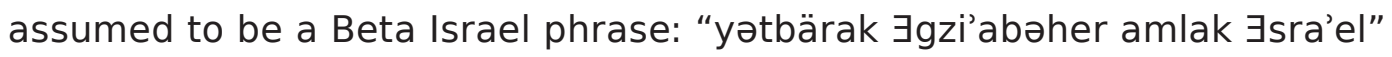
("Blessed be the Lord God"; Schneider 1963). He suggests that, given the obviously Christian nature of these and some other manuscripts, "this is further evidence for the adoption of Ethiopian Orthodox theological elements during the ethnogenesis of the Betä $\exists$ sra'el" (316).

More generally, Dege-Müller can be seen to be building on the initial insight of Verena Krempel (1982), who pointed out that many of the references to Jews (Ayhud) in Ge'ez literature are not concerned with the Beta Israel, but with a general category of heretics and rebels. Only with this insight is it possible to begin to distinguish actual references to the ethnic group known from at least the early sixteenth century as the "Fälasha" and a host of other dissidents who flourished in Christian Ethiopia.

Here, too, it is valuable to have her translation of a portion from Gadlä Gäbrä lyäsus, which was originally published by the great Italian scholar Carlo Conti Rossini (1938). According to this source, a dog who was carrying 
food on his back "encountered two Jews herding cattle. These Jews were from that tribe of Jews that had fled the destruction of Jerusalem under Vespasian and Titus and had migrated to Ethiopia" (see Annex 3 of Sophia Dege-Müller's article in this volume). Although this saint lived in the fouteenth century, his gädl was only written (or re-written) after the original version had been lost in the Muslim conquest of Ahmad Gragn (15061543). Significantly, although the author uses the verb fälaśa to indicate the migration of the Jews from the land of Israel, he does not connect this to the name Fälaśa. This probably indicates that the term was not (yet) widely used. Moreover, this is the first local Ethiopian source to identify Jews in Ethiopia not as Christian apostates, but as immigrants from the land of Israel, an origin story which will eventually develop into a guiding ideology for the group and its supporters.

Among the many lacunae in the study of the Beta Israel, material culture and historical archaeology are among the most prominent. One need not look far to grasp the reasons for this gap. Until recent years, historical archaeology has received comparatively little attention in Ethiopia in comparison to both pre-history and the study of proto-, pre-, and Aksumite civilization. In addition, there was comparatively little perception of the Beta Israel as a historical people. Because they were viewed as a survival from the Aksumite period, there seemed little point in documenting how their lives had changed over time. Indeed, in one of the most glaring misreadings of material culture, "Fälaśa" figurines produced beginning in the 1960s with the help of foreign visitors were identified as pre-historic fertility idols (Meinardus 1966, cf. Gamst 1972, Gamst and Baldia 1980, Kaplan and Rosen 1996). Finally, it should of course be noted that the researchers and visitors who visited Beta Israel villages in the late 1960s and early 1970s 
had little reason to believe that they would soon be uprooted and that valuable memories of sites would be displaced if not lost altogether.

In this context, the contribution of Kribus and Krebs is quite remarkable and leaves the reader eager to receive further information on this and other sites. Combining the skills of an archaeologist and a historian, with special sensitivity to artefacts and culture, they offer not only their findings but also deep insight into the research process. In contrast to the only previous work of this kind by Klein (2007), Kribus and Krebs seek not to uncover the riches of a major urban location-Gondar-but rather hope to uncover identifiable monastic remains in relatively isolated areas. Since Beta Israel "monasteries" appear to have been made up of simple huts rather than large stone structures, the challenge is considerable. As is clear from the present article, intensive collection of both oral and written sources was necessary to even begin the process of identifying where to search. Thus, even prior to departing for Ethiopia, the authors undertook meticulous work in surveying written sources and supplementing these with oral histories from Beta Israel migrants in Israel. This has then been supplemented with local knowledge from remaining (generally non-Beta Israel) residents. Finds such as remains of a mäsgid/şalota bet (prayer house) as well as cemetery and smithing tools support a possible identification certainly significant. In this context it should be noted that although the Beta Israel generally belonged to the category of despised craftsmen in Ethiopia (Abbink 1987; Quirin 1992), the line between monasticism and artisans was not always clear (Heldman 2013).

As was noted above, Shelemay and Quirin, each in his/her own way, made a powerful case for the centrality of Beta Israel monasticism in the development of community identity. Moreover, already in the last century, Taamrat Emanuel had shared his knowledge of holy places (Leslau 1974), a survey supplemented by Shoshana Ben Dor (1985) in Israel. None of these 
scholars, however, sought to identify the sites or bring to bear the methods and insights of archaeology.

The current pilot project has revealed that using a combination of existing written sources and the still vivid memories of the Beta Israel's mainly Christian neighbors, it is possible to make significant progress on identifying and unearthing material remains. Although the political situation in Ethiopia made it difficult to immediately follow up on this work in 2016, most recently an additional field season in the fall of 2017 has provided rich supplemental material.

While both articles "printed" in this journal share the conviction that the Beta Israel are best understood in the broader context of Christian Ethiopia, they differ markedly in method and purpose. Sophia Dege-Müller has begun the process of reviving a textually-based form of analysis which has largely been dormant for the past quarter century. Krebs and Kribus move boldly into the neglected realm of historical archaeology. Both contributions are of the highest quality and hold the promise of further revelations. Moreover, they move us forward in several of the paths in Beta Israel studies suggested above: the historical analysis of Jewish-Hebraic elements in Ethiopia, the revitalization of the study of Beta Israel literature, and the greater recognition of the importance of oral traditions.

\section{Reference List}

Abbink, Jon. 1987. “A Socio-Structural Analysis of the Beta Esra'el as an 'Infamous Group' in Traditional Ethiopia." Sociologus 37 (2): 140-154.

Abbink, Jon. 1990. “The Enigma of Bete Isra'el Ethnogenesis: An AnthroHistorical Study." Cahiers d'études africaines 30 (120): 397-449. 
Aescoly, Aaron Zeev. 1951. Recueil de textes Falashas. Paris: Institut d'ethnologie.

Bausi, Alessandro, ed. 2017. Languages and Cultures of Eastern Christianity: Ethiopia. London: Routledge.

Ben-Dor, Shoshana. 1985. “Ha-Meqomot ha-Qədošim šel Yehudey 'Etiyopiyah." [The Holy Places of Ethiopian Jewry] Pe'amim 22: 32-52.

Devens, Monica S., ed. 1995. The Liturgy of the Seventh Sabbath: A Betä Israel (Falasha) Text. Wiesbaden: Otto Harrassowitz Verlag.

Erho, Ted. 2017. “The Library and Old Testament Manuscripts of Gundä Gunde." In Studies in Ethiopian Languages, Literature, and History: Festschrift for Getatchew Haile Presented by his Friends and Colleagues, Aethiopistische Forschungen Vol. 83, edited by Adam Carter McCollum, 297-319. Wiesbaden: Otto Harrassowitz Verlag.

Gamst, F.C., and M.O. Baldia. 1980. "The So-called Fertility Idols of the Falasha of Abyssinia." Zeitschrift fur Ethnologie 105 (1-2): 134144.

Gamst, Frederick C. 1992. “Zur Zufälligkeit der Entstehung neuer Kunststile: Ergänzungen zum Aufsatz über die sogenannten 'Fruchtbarkeitsidole' der Falascha von Abessinien." Zeitschrift für Ethnologie 117: 117-118.

Halévy, Joseph. 1902. Te'ezâza Sanbat (commandement du sabbat). Accompagne de Six Autres Ecrits Pseudo-Epigraphiques Admis par les Falachas ou Juifs dAbyssinie. Bibliotheque de I'Ecole des Hautes Etudes. Sciences Historiques et Philologiques 137. Paris: Librairie Émile Bouillon. 
Heide, Martin. 2012. Das Testament Abrahams: Edition und Übersetzung der arabischen und äthiopischen Versionen. Aethiopistische Forschungen, vol. 76. Wiesbaden: Harrassowitz.

Heldman, Marilyn E. 2003. "Church buildings." In Encyclopaedia Aethiopica I, 737-742. Wiesbaden: Harrassowitz.

Heldman, Marilyn E. 2013. “Creating religious art: the status of artisans in highland Christian Ethiopia." Aethiopica 1 (1): 131-147.

Johnson, David W. 1995. "Dating the Kebra Nagast: another look." In Peace and war in Byzantium: essays in honor of George T. Dennis, SJ, edited by Timothy S. Miller, and John Nesbitt, 197208. Washington DC: Catholic University of America Press.

Kaplan, Steven. 1990. “Mehquar ha-Sifrut šel Beyta’ Yisra'el: Hesegim və-Ye'adim." [The Literature of the Beta Israel: Retrospect and Prospect] Pe'amim 41: 90-111.

- - - 1992. The Beta Israel (Falasha) in Ethiopia. From the Earliest Times to the Twentieth Century. New York: New York University Press.

Kaplan, Steven, and Chaim Rosen. 1996. “Created in Their Own Image: A Comment on Beta Israel Figurines (Créés à leur image: une analyse des statuettes beta Israel)." Cahiers d'études africaines: 171-182.

Kaplan, Steven, and Hagar Salamon. 2014. “Ethiopian Immigrants in their Israeli Context: Some Introductory Framings." In Social, Cultural and Clinical Aspects of Ethiopian Immigrants in Israel, edited by Eliezer Witztum, and Nimrod Grisaru, 21-36. Beer Sheva: Ben Gurion University Press.

Kaufman Shelemay, Kay. 1989. Music, Ritual, and Falasha History. East Lansing: Michigan State University Press. 
Klein, Rebecca A. 2007. "We Do Not Eat Meat with the Christians: Interaction and Integration between the Beta Israel and Amhara Christians of Gonder, Ethiopia." PhD diss., University of Florida. Leslau, Wolf. 1951. Falasha Anthology. New Haven: Yale University Press. - - . 1974. “Taamrat Emanuel's Notes of Falasha Monks and Holy Places." In Salo Wittmayer Baron. Jubilee Volume on the Occasion of his Eightieth Birthday, edited by Saul Liebermann, and Arthur Hymann, 623-637. New York: Columbia University Press.

Meinardous, Afa. 1966. "Fertility Idols of the Abyssinian Jews (Falashas)." Zeitschrift fur Ethnologie 91 (1): 127-130.

Munro-Hay, Stuart. 2001 "A Sixth Century Kebra Nagast?" Annales d'Éthiopie 17 (1): 43-58.

Polotsky, Hans Jacob. 1964. "Aramaic, Syriac, and Ge'ez." Journal of Semitic Studies 9: 1-10.

Quirin, James. 1992. The Evolution of the Ethiopian Jews: a History of the Beta Israel (Falasha) to 1920. The Ethnohistory Series. Philadelphia: University of Pennsylvania Press.

Rodinson, Maxime. 1964a. "Review of Edward Ullendorff, The Ethiopians: Introduction to Country and People." Bibliotheca Orientalis 21 (3-4): 238-245.

_-_. 1964b. "Sur la Question des 'Influences Juives' en Ethiopie." Journal of Semitic Studies 9 (1): 11-19.

Rubenson, Sven. 1965. "The Lion of the Tribe of Judah Christian Symbol and/or Imperial Title." Journal of Ethiopian Studies 3 (2): 75-85.

Salamon, Hagar. 1994. "Slavery among the 'Beta-Israel' in Ethiopia: Religious Dimensions of Inter-group Perceptions." Slavery and Abolition 15 (1): 72-88.

-_-. 1999. The Hyena People: Ethiopian Jews in Christian Ethiopia. Berkeley: University of California Press. 
- - . 2003. "Blackness in Transition: Decoding Racial Constructs through Stories of Ethiopian Jews." Journal of Folklore Research 40 (1): 3-32.

_- - 2008. "Cow Tales: Decoding Images of Slavery in the Ethiopian Jewish Community." Slavery \& Abolition 29 (3): 415-35.

_- - 2015. "Cutting into the Flesh of the Community: Ritual Slaughter, Meat Consumption, and the Transition from Ethiopia to Israel." Studies in Contemporary Jewry 28: 110-45.

Schneider, Roger. 1963. "La bibliothèque du couvent de GoundaGoundé." Tarik 2: 45-46.

Shahid, Irfan. 1976. "The Kebra Nagast in the light of recent research." Le Muséon 89: 133-178.

Ullendorff, Edward. 1956. "Hebraic-Jewish Elements in Abyssinian (Monophysite) Christianity." Journal of Semitic Studies 1: 216256.

- - . 1961. "The 'Death Of Moses' in the Literature of the Falashas." Bulletin of the School of Oriental and African Studies 24 (3): 419443.

Wurmbrand, Max, ed. and tr. 1961. The Death of Aaron. Tel Aviv: Friends of Faitlovitch Library.

- - . 1962 "Remarks on the Test of the Falasha 'Death of Moses'." Bulletin of the School of Oriental and African Studies 25 (3): 431437.

_-_. 1963a. "A Falasha Variant of the Story of Susanna." Biblica 44 (1): 29-45.

_-_. 1963b. “Le'Dersana Sanbat'-une Homélie Éthiopienne attribuée à Jacques de Saroug." L'Orient Syrien 8:343-394. 